\title{
HCRT Gene
}

National Cancer Institute

\section{Source}

National Cancer Institute. HCRT Gene. NCI Thesaurus. Code C106419.

This gene is involved in neuropeptide signaling. 